\title{
KARAKTERISTIK PAPAN PARTIKEL LIMBAH KAYU MAHONI DENGAN PERLAKUAN PENGAWETAN ASAP CAIR
}

\author{
Agus Ngadianto ${ }^{1}$, Ragil Widyorini ${ }^{2}$, Ganis Lukmandaru ${ }^{3}$ \\ ${ }^{1}$ Program Studi Pengelolaan Hutan/Departemen Teknologi Hayati dan Veteriner/Sekolah Vokasi, Universitas Gadjah Mada, Indonesia \\ Email: 1agus.ng@ugm.ac.id \\ 2,3Program Studi Ilmu Kehutanan/Fakultas Kehutanan, Universitas Gadjah Mada, Indonesia \\ Email: ${ }^{2}$ rwidyorini@ugm.ac.id, ${ }^{3}$ ganisarema@lycos.com
}

\begin{abstract}
This research focused on the characteristics of particleboard made from preservation treated-particles. Mahagony wood biomass waste was used as raw material. Liquid smoke at different concentrations (0\%, 2.5\%, and 5\%) was applied for 24 hours onto the particles. After dried in air dry condition, the particles were mixed with urea formaldehyde resin $(7.5 \%$ and $15 \%$ ), and then were pressed using hot pressing system at $150^{\circ} \mathrm{C}$ for 10 minutes. The result showed that the particleboard using $15 \%$ urea formaldehyde resin and made form $5 \%$ liquid smoke treated-particles provided the best performance, that met Japanese Industry Standard (JIS) A 5908. The mortality value of dry wood termites Cryptotermes cynocephalus Light and the weight loss after termite attack at the same condition were $90.67 \%$ and $0.408 \%$, respectively.
\end{abstract}

Keywords: liquid smoke, Mahagony, particleboard, preservation.

\section{PENDAHULUAN}

Papan partikel merupakan salah satu produk papan tiruan yang banyak digunakan oleh masyarakat sebagai pengganti kayu yang ketersediannya semakin terbatas. Kelebihan produk ini antara lain: papan partikel bebas cacat seperti mata kayu, ukuran dan kerapatannya dapat disesuaikan dengan kebutuhan, mempunyai sifat isotropis, serta sifat dan kualitasnya dapat diatur. Sementara itu, kelemahan produk papan partikel ini adalah stabilitas dimensinya yang rendah sehingga sangat besar pengaruhnya pada pemakaian terutama bila digunakan sebagai bahan bangunan (Haygreen dan Bowyer, 1996). Pada saat ini terdapat 19 buah industri pembuatan papan partikel di Indonesia. Industri ini memanfaatkan limbah kayu dari industri pengolahan kayu sebagai bahan bakunya (Sutigno dalam Yuliansyah, 2001). Mahoni merupakan jenis kayu yang banyak dimanfaatkan dan digunakan dalam industri pengolahan kayu di Indonesia sehingga dapat diasumsikan bahwa limbah yang dihasilkan dari jenis kayu ini sangat tinggi sehingga dapat digunakan sebagai bahan pembuatan papan partikel yang sangat potensial.

Dalam pembuatan papan partikel, harus diperhatikan faktor-faktor yang berpengaruh terhadap sifat dan kekuatan papan partikel tersebut seperti jenis bahan, tipe dan ukuran partikel, penyebaran partikel, jenis dan jumlah perekat, kerapatan papan partikel, kadar air partikel dan perekatan partikel serta proses pembuatannya (Kollman et al., 1975). Jenis perekat yang umum digunakan dalam pembuatan papan partikel adalah perekat sintetis berbasis formaldehida, salah satunya adalah urea formaldehida. Jumlah perekat pada partikel merupakan salah satu faktor yang penting dalam menentukan sifat papan partikel yang dihasilkan. Semakin banyak perekat yang digunakan dalam pembuatan papan partikel, maka semakin kuat dan stabil dimensi papan. Namun demikian, dari segi ekonomi penggunaan perekat yang terlalu banyak tidak diinginkan (Haygreen dan Bowyer, 1996).

Selain sifat dan kekuatan papan partikel, sifat ketahanan dan keawetannya juga perlu diperhatikan agar memberikan umur pakai yang lebih lama dari produk ini. Usaha peningkatan keawetan papan partikel telah banyak dilakukan melalui pengawetan bahan baku kayunya, penambahan bahan pengawet pada perekat, maupun pengawetan papan partikel yang sudah jadi. Alternatif bahan pengawet yang dapat digunakan yaitu bahan pengawet yang beracun terhadap organisme perusak kayu namun bersifat ramah terhadap lingkungan seperti asap cair. Penggunaan asap cair sebagai bahan pengawet pada kayu solid sebelumnya telah banyak digunakan. Sementara itu, penelitian mengenai pengawetan papan partikel menggunakan bahan pengawet ini belum pernah dilakukan. Penelitian ini bertujuan untuk mengetahui interaksi antara perlakuan pengawetan dengan asap cair dan jumlah perekat urea formaldehida yang digunakan pada pembuatan papan partikel dari limbah kayu mahoni (Swietenia macrophylla) sehingga diperoleh kombinasi yang tepat dalam meningkatkan sifat papan partikel serta ketahanannya terhadap serangan organisme perusak kayu seperti rayap dan jamur. Namun, dalam penelitian ini akan dicoba pada rayap kayu kering Cryptotermes cynocephalus Light. 


\section{BAHAN DAN METODE PENELITIAN}

\subsection{Bahan Penelitian}

Bahan baku yang digunakan dalam penelitian ini adalah partikel kayu mahoni (Swietenia macrophylla). Partikel kayu tersebut disaring sehingga lolos saringan $0,5 \mathrm{~cm}$ x $0,5 \mathrm{~cm}$ dan tertahan saringan ukuran 40 mesh serta dikeringkan sampai mencapai kadar air kering udara dengan kisaran dibawah 13\%. Bahan pengawet yang digunakan adalah asap cair dari tempurung kelapa dengan kandungan acetic acid sebanyak 53,37\% dan phenol sebanyak 38,67\%. Perekat yang digunakan dalam pembuatan papan partikel ini adalah urea formaldehida dengan pH 8-9 dan kekentalan 2-3,2 poise.

\subsection{Perlakuan Pendahuluan}

Perlakuan pendahuluan terhadap partikel kayu dilakukan dengan perendaman partikel kayu ke dalam larutan bahan pengawet dengan berbagai perlakuan pengawetan, yaitu tanpa perlakuan pengawetan, perlakuan pengawetan dengan konsentrasi asap cair $0 \%$ (hanya direndam air); $2,5 \%$; dan 5\% selama 24 jam. Larutan bahan pengawet dibuat berdasarkan perbandingan berat (w/w) dimana partikel seberat $3 \mathrm{~kg}$ diawetkan dalam $20 \mathrm{~kg}$ larutan bahan pengawet dengan konsentrasi bahan pengawet asap cair sebesar $0 \% ; 2,5 \%$; dan 5\% dari berat larutan bahan pengawet tersebut. Partikel kemudian dikeringkan sampai mencapai kadar air kering udara dan siap dicampur dengan perekat urea formaldehida dengan jumlah perekat 7,5\% dan 15\%. Sebelum dan sesudah perlakuan pengawetan, berat partikel ditimbang sehingga diperoleh persen pertambahan beratnya (WPG, weight percent gain). Selain itu juga diukur kadar air partikel dan nilai wetabilitasnya dengan Metode CWAH (Corrected Water Absorption Height).

\subsection{Pembuatan Papan Partikel}

Papan partikel dibuat dengan ukuran $25 \mathrm{~cm}$ x $25 \mathrm{~cm}$ x $1 \mathrm{~cm}$ dan kerapatannya $0,8 \mathrm{~g} / \mathrm{cm}^{3}$. Perekat urea formaldehida yang dicampurkan dengan partikel sebanyak 7,5\% dan 15\% dari berat kering udara partikelnya. Papan partikel dibuat dengan kempa panas pada suhu $150^{\circ} \mathrm{C}$ dan tekanan manomerik $40 \mathrm{MPa}$ selama 10 menit. Untuk setiap kombinasi perlakuan dibuat tiga papan partikel sebagai ulangan.

\subsection{Pengujian Sifat Fisika dan Mekanika Papan Partikel}

Pengujian sifat fisika dan mekanika papan partikel ini meliputi kadar air, pengembangan tebal, penyerapan air, keteguhan rekat internal, dan keteguhan lengkung statik (MoE dan MoR) papan partikel. Standar pengujian yang digunakan adalah JIS A 5908-2003.

\subsection{Pengujian Papan Partikel terhadap Serangan Rayap Kayu Kering}

Pengujian terhadap serangan rayap kayu kering dilakukan dengan mengumpankan 50 ekor rayap kayu kering dewasa, sehat, dan aktif pada contoh uji papan partikel selama 6 minggu. Mortalitas rayap dihitung dengan membandingkan jumlah rayap yang mati terhadap jumlah rayap awal yang diumpankan dan dinyatakan dalam persen (\%), sedangkan nilai kehilangan berat contoh uji dihitung dengan membandingkan selisih antara berat awal contoh uji sebelum pengumpanan dengan berat akhir contoh uji setelah pengumpanan terhadap berat awal contoh uji sebelum pengumpanan yang dinyatakan dalam persen (\%).

\section{HASIL DAN PEMBAHASAN}

\subsection{Kadar Air, Wetabilitas, dan Persen Pertambahan Berat/WPG Partikel Mahoni}

Tabel 1. Nilai kadar air, wetabilitas, dan persen pertambahan berat partikel

\begin{tabular}{clccc}
\hline No & Sampel perlakuan & $\begin{array}{c}\text { Kadar air partikel } \\
\mathbf{( \% )}\end{array}$ & $\begin{array}{c}\text { Wetabilitas } \\
(\mathbf{m m})\end{array}$ & $\begin{array}{c}\text { WPG } \\
(\mathbf{\%}) *\end{array}$ \\
\hline 1 & Mahoni, tanpa perlakuan & 12,28 & 318,17 & - \\
2 & Mahoni, pengawetan 0\% & 8,83 & 406,67 & 0,09 \\
3 & Mahoni, pengawetan 2,5\% & 9,56 & 451,06 & 0,43 \\
4 & Mahoni, pengawetan 5\% & 9,47 & 480,74 & 0,62 \\
\hline * Berdasarkan berat kering tanur
\end{tabular}

Nilai kadar air partikel setelah perlakuan pengawetan memberikan nilai yang lebih kecil dari kadar air partikel tanpa perlakuan pengawetan, hal ini sesuai dengan pernyataan bahwa kadar air partikel akan mengalami penurunan setelah 
diberikan perlakuan terhadapnya (Haygreen dan Bowyer, 1996). Nilai wetabilitas partikel mahoni menunjukkan nilai yang semakin naik setelah perlakuan pengawetan pada berbagai konsentrasi. Kenaikan ini diduga karena bahan pengawet berupa asap cair dapat menyebabkan sifat higroskopisitas kayu meningkat.

Pada perlakuan pengawetan partikel kayu, nilai persen pertambahan berat (WPG) meningkat seiring besarnya konsentrasi bahan pengawet yang berikan. Nilai persen pertambahan berat pada partikel kayu ini terbilang kecil. Penelitian lain yang dilakukan oleh Suryono (2009) yang mencoba mengawetkan kayu solid (kayu karet) dengan bahan pengawet asap cair pada konsentrasi 30\% ditambah borak $6 \%$ memberikan nilai retensi sebesar $27,68 \mathrm{~kg} / \mathrm{m}^{3}$ atau sebesar $1,72 \%$ (berat jenis kayu karet 0,62). Besarnya retensi tersebut telah dapat memberikan nilai mortalitas rayap tanah sebesar $100 \%$.

\section{Pengujian Sifat Fisika dan Mekanika Papan Partikel Mahoni}

Tabel 2. Nilai pengujian sifat fisika dan mekanika papan partikel mahoni

\begin{tabular}{clcccccc}
\hline No & \multicolumn{1}{c}{ Sampel perlakuan } & $\begin{array}{c}\text { KA } \\
\mathbf{( \% )}\end{array}$ & $\begin{array}{c}\text { WA } \\
\mathbf{( \% )}\end{array}$ & $\begin{array}{c}\text { TS } \\
\mathbf{( \% )}\end{array}$ & $\begin{array}{c}\text { IB } \\
\left(\mathbf{k g} / \mathbf{c m}^{2}\right)\end{array}$ & $\begin{array}{c}\text { MoR } \\
\left(\mathbf{k g f} / \mathbf{c m}^{2}\right)\end{array}$ & $\begin{array}{c}\text { MoE } \\
\left(\mathbf{k g f} / \mathbf{c m}^{2}\right)\end{array}$ \\
\hline 1 & Mahoni TP, perekat 7,5\% & 8,36 & 73,14 & 11,80 & 5,658 & 72,720 & 9995.042 \\
2 & Mahoni TP, perekat 15\% & 7,63 & 38,85 & 5,84 & 6,001 & 136,079 & 20120.212 \\
3 & Mahoni 0\%, perekat 7,5\% & 6,34 & 78,27 & 17,68 & 5,222 & 68,560 & 10092.678 \\
4 & Mahoni 0\%, perekat 15\% & 5,59 & 46,38 & 8,88 & 5,892 & 129,686 & 17661.070 \\
5 & Mahoni 2,5\%, perekat 7,5\% & 8,97 & 86,65 & 18,70 & 3,919 & 56,241 & 9501.879 \\
6 & Mahoni 2,5\%, perekat 15\% & 7,60 & 55,59 & 12,81 & 8,588 & 130,417 & 19071.971 \\
7 & Mahoni 5\%, perekat 7,5\% & 8,90 & 81,26 & 17,26 & 5,027 & 69,398 & 11168.755 \\
8 & Mahoni 5\%, perekat 15\% & 7,41 & 50,25 & 10,13 & 7,231 & 143,033 & 21671.720 \\
\hline & Standar JIS A 5908-2003 & $5-13$ & - & Maks. 12 & Min. 1,5 & Min. 82 & Min 20,40 x 1030 \\
\hline
\end{tabular}

Tabel 3. Analisis varians sifat fisika dan mekanika papan partikel mahoni

\begin{tabular}{lccc}
\hline \multirow{2}{*}{ Parameter } & \multicolumn{3}{c}{ Mahoni } \\
\cline { 2 - 4 } & Perlakuan pengawetan & Jumlah perekat & Interaksi \\
\hline Kadar air & $0,000^{* *}$ & $0,000^{* *}$ & $0,030^{*}$ \\
Penyerapan air & $0,000^{* *}$ & $0,000^{* *}$ & $0,633^{\text {ns }}$ \\
Pengembangan tebal & $0,002^{* *}$ & $0,000^{* *}$ & $0,800^{\text {ns }}$ \\
Keteguhan rekat Internal & $0,348^{\text {ns }}$ & $0,000^{* *}$ & $0,000^{* *}$ \\
Modulus patah & $0,023^{*}$ & $0,000^{* *}$ & $0,271^{\text {ns }}$ \\
Modulus elastisitas & $0,054^{\text {ns }}$ & $0,000^{* *}$ & $0,389^{\text {ns }}$ \\
\hline
\end{tabular}

Keterangan: $\quad * *=$ Nilai sangat berbeda nyata pada taraf uji $1 \%$.

$*=$ Nilai sangat berbeda nyata pada taraf uji $5 \%$. ns $=$ Nilai tidak berbeda nyata.

Nilai kerapatan papan partikel mahoni pada penelitian ini seluruhnya diperoleh tanpa mengalami delaminasi dengan kisaran kerapatan antara 0,702-0,812 g/ $\mathrm{cm}^{3}$. Nilai ini telah mendekati nilai kerapatan yang dituju, yaitu $0,8 \mathrm{~g} / \mathrm{cm}^{3}$. Nilai kadar air, penyerapan air, dan pengembangan tebal papan partikel mahoni (Tabel 2) menurun dengan pertambahan jumlah perekat. Hasil analisis varians menunjukkan bahwa faktor perlakuan pengawetan dan faktor jumlah perekat memeberikan pengaruh yang sangat nyata pada ketiga parameter tersebut, namun hanya parameter kadar air papan partikel saja yang memberikan pengaruh nyata pada interaksinya (Tabel 3).

Perlakuan jumlah perekat yang lebih banyak mencukupi untuk membentuk ikatan antar partikel yang memadai serta menutup rongga-rongga di antara partikel sehingga papan lebih sulit untuk menyerap air. Ikatan antar partikel yang makin kuat menyebabkan rongga atau pori di antara jalinan partikel pada papan partikel tidak banyak yang dapat diisi oleh air sehingga kadar air, penyerapan air, dan pengembangan tebal papan menjadi kecil (Sutigno dalam Yusliansyah, 2001). Sementara itu, perlakuan pengawetan justru meningkatkan ketiga nilai parameter tersebut. Hal ini disebabkan karena perlakuan pengawetan dengan asap cair menyebabkan bertambahnya sifat higroskopis papan partikel. Nilai kadar air papan partikel mahoni pada penelitian ini telah memenuhi standar JIS A 5908-2003, nilai penyerapan air tidak disyaratkan 
dalam standar ini, sementara itu nilai pengembangan tebal papan partikel mahoni hanya sebagian saja yang memenuhi standar JIS A 5908-2003. Penelitian lain yang dilakukan Aini et al. (2009) menunjukkan bahwa nilai kadar air bambu laminasi meningkat dari 12,02\% menjadi 12,76\% setelah diawetkan dengan bahan pengawet boron dibandingkan dengan bambu laminasi tanpa perlakuan. Mendes et al. (2009) meneliti pengaruh perekat pada sifat papan partikel ampas tebu memberikan nilai pengembangan tebal yang semakin menurun dari 18,41\% menjadi 5,77\% dengan bertambahnya jumlah perekat urea formaldehida dari 6\%-12\%.

Nilai analisis varians keteguhan rekat internal papan partikel mahoni (Tabel 3) memberikan pengaruh yang sangat nyata pada faktor jumlah perekat dan interaksi antara perlakuan pengawetan dan jumlah perekat. Nilai keteguhan rekat internal ini meningkat dengan pertambahan jumlah perekat, karena ikatan dan rakitan antar partikel yang dibentuk akan semakin kuat dengan jumlah perekat yang semakin tinggi. Widarmana dalam Dirhamsyah (1995) mengungkapkan bahwa keteguhan rekat internal tidak dipengaruhi secara nyata oleh kerapatan kayu asalnya, akan tetapi lebih banyak ditentukan oleh faktor lainnya seperti geometri partikel, kerapatan lembaran, dan jumlah perekat. Sementara itu, perlakuan pengawetan cenderung menurunkan nilai ini jika dibandingkan dengan contoh uji tanpa perlakuan. Walaupun demikian, semua nilai keteguhan rekat internal pada papan partikel mahoni telah memenuhi standar JIS A 5908-2003.

Nilai modulus patah papan partikel mahoni setelah dianalisis varians memberikan pengaruh yang nyata pada faktor perlakuan pengawetan dan pengaruh yang sangat nyata pada faktor jumlah perekat, sedangkan interaksi antara keduanya tidak berpengaruh nyata. Modulus patah papan partikel meningkat dengan bertambahnya jumlah perekat. Banyaknya jumlah perekat yang digunakan menyebabkan ikatan antar partikel makin kuat sehingga nilai kerapatan akan makin tinggi yang akan meningkatkan nilai modulus patah papan partikel. Yahya dan Kader (1998) menyatakan bahwa meningkatnya kerapatan papan partikel dapat meningkatkan nilai modulus patah papan partikel. Penelitian yang dilakukan oleh Mendes et al. (2009) mengenai pengaruh perekat pada sifat papan partikel dari ampas tebu juga memberikan nilai modulus patah yang meningkat dari $80,75 \mathrm{kgf} / \mathrm{cm}^{2}$ menjadi $107,47 \mathrm{kgf} / \mathrm{cm}^{2}$ dengan bertambahnya jumlah perekat urea formaldehida dari $6 \%$ menjadi $12 \%$. Sementara itu, perlakuan pengawetan cenderung menurunkan nilai ini sehingga hanya sebagian perlakuan saja yang memenuhi standar JIS A 5908-2003.

Nilai modulus elastisitas papan partikel setelah dianalisis varians memberikan pengaruh yang sangat nyata hanya pada faktor jumlah perekat saja. Hal ini disebabkan penambahan perekat akan meningkatkan ikatan antar partikel sehingga nilai ini semakin meningkat namun hanya sebagian saja yang memenuhi standar JIS A 5908-2003.

\section{Pengujian terhadap Serangan Rayap Kayu Kering}

Tabel 4. Nilai mortalitas rayap dan kehilangan berat papan partikel mahoni

\begin{tabular}{clcc}
\hline No & \multicolumn{1}{c}{ Sampel perlakuan } & Mortalitas rayap (\%) & Kehilangan berat (\%) \\
\hline 1 & Mahoni TP, perekat 7,5\% & 66,00 & 0,847 \\
2 & Mahoni TP, perekat 15\% & 83,33 & 0,772 \\
3 & Mahoni 0\%, perekat 7,5\% & 72,67 & 0,730 \\
4 & Mahoni 0\%, perekat 15\% & 84,00 & 0,614 \\
5 & Mahoni 2,5\%, perekat 7,5\% & 86,00 & 0,637 \\
6 & Mahoni 2,5\%, perekat 15\% & 85,33 & 0,625 \\
7 & Mahoni 5\%, perekat 7,5\% & 87,33 & 0,565 \\
8 & Mahoni 5\%, perekat 15\% & 90,67 & 0,408 \\
\hline
\end{tabular}

Tabel 5. Nilai analisis varians mortalitas rayap dan kehilangan berat papan partikel mahoni

\begin{tabular}{|c|c|c|c|}
\hline \multirow{2}{*}{ Parameter } & \multicolumn{3}{|c|}{ Mahoni } \\
\hline & Perlakuan pengawetan & Jumlah perekat & Interaksi \\
\hline Mortalitas rayap & $0,007^{* *}$ & $0,012 *$ & $0,208^{\mathrm{ns}}$ \\
\hline Kehilangan berat & $0,000 * *$ & $0,041^{*}$ & $0,630^{\mathrm{ns}}$ \\
\hline
\end{tabular}


Nilai mortalitas rayap pada papan partikel mahoni tertinggi diperoleh pada perlakuan pengawetan dengan konsentrasi 5\% dan jumlah perekat 15\%, yaitu sebesar 90,67\%. Hasil analisis varians (Tabel 5) menunjukkan bahwa faktor perlakuan pengawetan berpengaruh sangat nyata dan faktor jumlah perekat berpengaruh nyata terhadap nilai mortalitas rayap. Hasilnya menunjukkan bahwa semakin besar konsentrasi bahan pengawet yang diberikan, maka nilai mortalitas rayapnya akan semakin tinggi (Gambar 1). Hal tersebut sesuai dengan pernyataan Hunt dan Garrat (1986) yaitu nilai mortalitas semakin naik dengan semakin bertambahnya konsentrasi bahan pengawet yang diberikan.

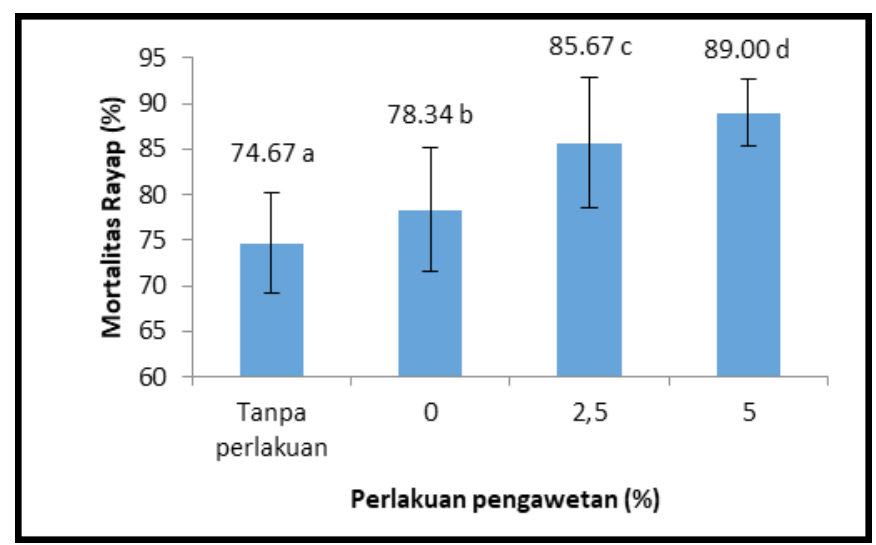

\section{Gambar 1. Grafik nilai uji HSD perlakuan pengawetan terhadap mortalitas rayap pada papan partikel mahoni}

Keterangan: Angka yang disertai huruf yang berbeda menunjukkan perbedaan nyata pada taraf uji $\alpha 0,01$

$($ Nilai HSD $=0,177$ )

Perubahan nilai mortalitas rayap kayu kering yang makin meningkat dengan peningkatan konsentrasi bahan pengawet seperti ditunjukkan pada Gambar 1 diduga terjadi karena adanya kandungan fenol dan asam organik. Tranggono et al. (1997) menyatakan bahwa fenol dan asam organik merupakan senyawa utama di dalam asap cair yang bersifat bakteriostatik/baktersidal. Nilai mortalitas rayap papan tanpa perlakuan lebih rendah daripada nilai mortalitas rayap papan perendaman asap cair, hal ini membuktikan bahwa asap cair mampu menaikkan nilai mortalitas rayap. Selain itu, tingginya nilai mortalitas rayap papan partikel pada konsentrasi asap cair $0 \%$ dibandingkan dengan papan partikel tanpa perlakuan diduga karena pengaruh perekat urea formaldehidanya. Penelitian lain yang dilakukan oleh Indrayani et al. (2010) memberikan hasil bahwa mortalitas rayap meningkat dengan naiknya konsentrasi asap cair dari $1 \%-4 \%$ serta tingginya suhu pirolisis $450^{\circ} \mathrm{C}$ dengan nilai mortalitas rayap mencapai $100 \%$. Sementara itu, Walther et al. (2007) yang menggunakan impregnasi phenol formaldehida pada papan partikel kenaf menyebabkan nilai mortalitas rayap mencapai hampir 100\% serta Sulastiningsih dan Jasni (2004) dalam penelitiannya mengenai ketahanan papan partikel dari kayu karet terhadap rayap kayu kering yang menggunakan bahan pengawet alfametrin pada konsentrasi $0,75 \%$ memberikan nilai mortalitas rayap $100 \%$.

Nilai kehilangan berat terkecil pada papan partikel mahoni diperoleh pada kombinasi perlakuan pengawetan 5\% dan jumlah perekat 15\%, yaitu sebesar 0,408\%. Hasil analisis varians pada Tabel 5 menunjukkan bahwa faktor perlakuan pengawetan memberikan pengaruh yang sangat nyata dan faktor jumlah perekat berpengaruh nyata terhadap nilai kehilangan berat, sedangkan interaksi antara keduanya tidak memberikan pengaruh nyata. Nilai kehilangan berat papan partikel mahoni menurun dengan peningkatan konsentrasi bahan pengawet asap cair yang diberikan (Gambar 2). Hal ini sesuai dengan pernyataan Hunt dan Garrat (1986) yang menyatakan bahwa semakin tinggi konsentrasi bahan pengawet yang diberikan, maka semakin kecil nilai kehilangan berat yang diperoleh dan berbanding terbalik dengan nilai mortalitas yang dihasilkan. Penelitian yang dilakukan oleh Indrayani et al. (2010) memberikan hasil bahwa kehilangan berat menurun bahkan tanpa mengalami kehilangan berat sedikitpun pada contoh uji dengan naiknya konsentrasi asap cair dari $1 \%-4 \%$ serta tingginya suhu pirolisis $450^{\circ} \mathrm{C}$. 


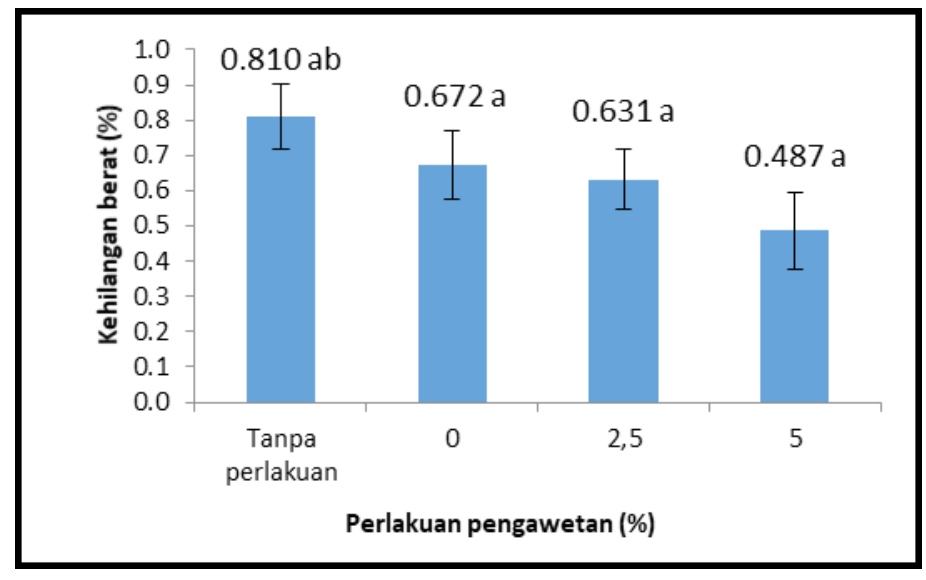

Gambar 2. Grafik nilai uji HSD perlakuan pengawetan terhadap kehilangan berat papan partikel mahoni

Keterangan: Angka yang disertai huruf yang berbeda menunjukkan perbedaan nyata pada taraf uji $\alpha 0,01$

(Nilai HSD $=0,212$ )

\section{KESIMPULAN}

1. Sifat fisika dan mekanika papan partikel mahoni telah memenuhi Standar JIS A 5908-1994, antara lain: kadar air, dan keteguhan rekat internal;

2. Hasil papan partikel mahoni terbaik diperoleh dari perlakuan pengawetan dengan konsentrasi $5 \%$ dan jumlah perekat 15\% dimana semua parameter yang diuji memenuhi standar JIS A 5908-2003;

3. Nilai mortalitas rayap dan nilai kehilangan berat terbaik pada papan partikel mahoni diperoleh pada kombinasi perlakuan pengawetan dengan konsentrasi bahan pengawet $5 \%$ dan jumlah perekat $15 \%$, yaitu sebesar $90,67 \%$ dan $0,408 \%$.

\section{DAFTAR PUSTAKA}

Aini, N., Morisco \& Anita. (2009). Pengaruh Pengawetan Terhadap Kekuatan dan Keawetan Produk Laminasi Bambu. Bandung: Balai Bahan Bangunan Puslitbang Permukiman.

Anonim. (2003). Japanese Industrial Standard Particleboards A 5908. Japan: Japanese Industrial Standard Association.

Dirhamsyah, M. (1995). Pengaruh Ekstraksi dan Cara Pengawetan terhadap Sifat Papan Partikel Kelapa Sawit. Tesis. Program Pasca Sarjana Fakultas Kehutanan. Universitas Gadjah Mada. Yogyakarta (Tidak diterbitkan).

Haygreen, J.G. \& J.L. Bowyer. (1996). Hasil Hutan dan Ilmu Kayu, Suatu Pengantar. Diterjemahkan oleh Dr. Ir. Sutjipto A. Hadikusumo. Yogyakarta: Gadjah Mada University Press.

Hunt, G.M. dan G.A. Garrat. (1986). Pengawetan Kayu. Diterjemahkan oleh Ir. Mohamad Jusuf (Alm.). Jakarta: CV Akademika Presindo.

Indrayani, Y. H.A. Oramahi, \& Nurhaida. (2010). Evaluation of Liquid Smoke as Bio-Pesticide to Control Subterranean Termites Coptotermes sp. Jurnal Ketawang Fakultas Kehutanan Universitas Tanjungpura Pontianak, 87-96.

Kollman, F.F.P., E.W Kwenzi, \& A.J. Stamm. (1975). Principles of Wood Science and Technology Vol II, Wood Based Materials. Springer Verlay Berlin Heidelberg. New York.

Mendes, R.F, L.M. Mendes, J.B.G. Junior, L.C.D. Santos, \& L. Bufalino. (2009). The Adhesive Effect on The Properties of Particleboards Made From Sugar Cane Bagasse Generated in The Distiller. Encontro Brasileiro em Madeiras e em Estruturas de Madeira. Londrina. Brasil.

Sulastiningsih, I.M., dan Jasni. 2004. Ketahanan Papan Partikel Terhadap Serangan Rayap Kayu Kering Cryptotermes cynocephalus Light. Jurnal Penelitian Hasil Hutan 22 (2): 69-74. 
Agus Ngadianto, Ragil Widyorini, Ganis Lukmandaru, Profil Glukosa Darah, Lipid, dan Visualisasi Pulau Langerhans Sebagai Imunoreaktor Insulin dan Glukagon Pada Pankreas Tikus (Rattus Norvegicus) Obesitas Menggunakan Teknik Imunohistokimia

Suryono, A. (2009). Asap Cair Tempurung Kelapa Sebagai Bahan Pengawet Kayu Karet dari Serangan rayap Tanah (Coptotermes curvignathus Holmgren). Tesis. Sekolah Pascasarjana Institut Pertanian Bogor. Bogor (Tidak Dierbitkan).

Tranggono, S., B. Setiadji, Darmadji, Supranto, Sudarmanto, \& R. Arumanto. (1997). Identifikasi Asap Cair dari Berbagai Jenis Kayu dan Tempurung Kelapa. Laporan Akhir Riset Unggulan Terpadu III (1995-1997). Yogyakarta.

Walther, T., S.N. Kartal, W.J. Hwang, K. Umemura \& S. Kawai. (2007). Strength, Decay and Termite Resistance of Oriented Kenaf Fiberboards. The Japan Wood Research Society, 53, 481-486.

Yahya, S.N. \& R.A. Kader. (1998). Properties of Particleboard Manufactures from Less Used Species I. Adhesive Technology and Bonded Tropical Wood Product. Taiwan: Taiwan Forestry Research Institute.

Yusliansyah, R., Maharani \& D.I. Fauzi. (2001). Sifat Partikel dari Jenis Kayu Hutan Sekunder dan Hutan Tanaman dengan Perekat Melamin Formaldehida. Prosiding Seminar Nasional IV. MAPEKI. 